\title{
NEW SUOID FOSSILS (MAMMALIA, ARTIODACTYLA) FROM THE MIOCENE OF MOGHARA, EGYPT, AND GEBEL ZELTEN, LIBYA: BIOCHRONOLOGICAL IMPLICATIONS
}

\author{
MARTIN PICKFORD ${ }^{1, *}$, MOHAMED ABDEL GAWAD ${ }^{2}$, MOHAMED HAMDAN $^{2}$, AHMED N. EL-BARKOOKY ${ }^{2}$, \\ MOHAMMED H. AL RIAYDH ${ }^{3}$

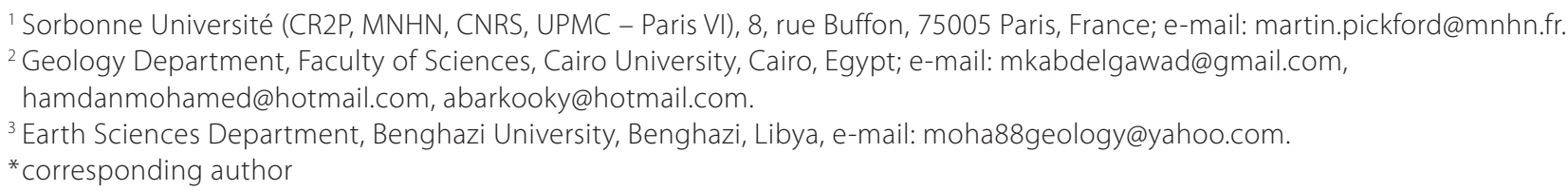

Pickford, M., Abdel Gawad, M., Hamdan, M., El-Barkooky, A. N., Al Riaydh, M. H. (2021): New suoid fossils (Mammalia, Artiodactyla) from the Miocene of Moghara, Egypt, and Gebel Zelten, Libya: biochronological implications. - Fossil Imprint, 77(1): 111-125, Praha. ISSN 2533-4050 (print), ISSN 2533-4069 (on-line).

\begin{abstract}
Some undescribed suoid specimens from early and middle Miocene deposits at Moghara, Egypt, and Gebel Zelten, Libya, are of interest for biochronology. The fossils comprise maxillae and mandibles with incomplete dentitions, which are described and illustrated in detail. Three species of suids and one sanithere occur at Moghara. A huge edentulous suid mandible was collected at Gebel Zelten in 1997 during the Spanish-Libyan Palaeontology Expedition. In January, 2020, additional sanithere fossils were collected from Moghara by a team from Cairo University and the Muséum National d'Histoire Naturelle, Paris. A suid mandible with four teeth collected from Moghara in 1994, and now curated at the Cairo Geological Museum, confirms the presence of the species Libycochoerus massai at the site, previously represented by an isolated upper molar and two canines. A talus previously thought to be from Moghara is now known to have been collected at Wadi Natrun (late Miocene) and thus probably represents a tetraconodont rather than a kubanochoere. The age of the Moghara deposits is estimated to span the period ca. 19.5-16.5 Ma (late early Miocene, Faunal Sets PII-PIIIa) and the Zelten sequence is most likely to span the period ca. 17-14.5 Ma (late early Miocene to basal middle Miocene, Faunal Sets PIIIa-PIIIb).
\end{abstract}

Key words: Suoidea, early Miocene, middle Miocene, biochronology, North Africa

Received: January 29, 2021 | Accepted: April 27, 2021 | Issued: December 9, 2021

\section{Introduction}

Fossil Suoidea from the early Miocene deposits at Moghara, Egypt, were described by Pickford et al. (2010) who used them to estimate the age of the sedimentary succession. The main conclusion of that paper was that the Moghara deposits span the period ca. 17.8 to $16.4 \mathrm{Ma}$. The second conclusion was that some of the deposits at Moghara span the same time period as part of the sequence at Gebel Zelten, Libya (Arambourg 1961, 1963). These conclusions were based on records at Moghara of the sanithere Diamantohyus africanus, and three species of suids - Nguruwe kijivium, cf. Libycochoerus jeanneli, and Libycochoerus massai. Gebel Zelten has yielded the same species of sanithere, but the suids from the sedimentary sequence comprise the large kubanochoeres Libycochoerus massai and Kubwachoerus khinzikebirus (Pickford 2006, Pickford and Tsujikawa 2019) which suggest that at Zelten there are some deposits that are younger than the youngest strata at Moghara.

The previous record of Libycochoerus massai from Moghara was based on three teeth - an isolated upper third molar curated at Cairo University (CUWM 132, field number WM Dec-06-09), two canine fragments and a talus (Pickford et al. 2010), the last specimen now known to have been collected at Wadi Natrun (late Miocene). In the Cairo Geological Museum (CGM) there is another suid specimen collected from Moghara in 1994, consisting of a mandible with four teeth $(\mathrm{p} / 4-\mathrm{m} / 3)$ which confirms the presence of this species at the site.

Undescribed suoids from Moghara are herein added to the material described by Pickford et al. (2010) and a huge edentulous mandible from Gebel Zelten is described in detail, previous mention of the fossil only recording the dimensions of the canine and the $\mathrm{m} / 2$ (Pickford 2006). 


\section{Material and methods}

The new suoid fossils from Moghara described herein were collected by the authors during field survey of Moghara during January, 2020, and are curated at Cairo University Geology Department under the abbreviation CUWM. The mandible from Gebel Zelten was collected in 1997 during the Spanish-Libyan Palaeontology Expedition and is curated at Benghazi University (ATH 6C 1) (Pickford 2006).

Images were captured with a Sony Cybershot Camera, and were treated using Photoshop Elements 15 to remove unwanted background, increase contrast and to convert them to black-and-white. Scales were added manually. Measurements of teeth follow the method outlined by van der Made (1996). Upper teeth are abbreviated in capital letters ( $\mathrm{I}$ - incisor, $\mathrm{C}$ - canine, $\mathrm{P}$ - premolar, $\mathrm{M}$ - molar) and lower teeth are in lower case (i, c, p, m, and d-deciduous premolar). The meristic position is above the forward slash (/) for upper teeth, (M1/, P4/ etc.) and below it for lower teeth $(\mathrm{m} / 1, \mathrm{p} / 4$ etc.), the forward slash representing the occlusal plane.

\section{Abbreviations}

BSPG Bayerische Staatssammlung für Paläontolgie und Geologie, Munich, Germany

BU Bristol University, Bristol, United Kingdom

CGM Cairo Geological Museum, Cairo, Egypt

CUWM Cairo University Wadi Moghara collection, Geology Department, Cairo University, Giza, Egypt

DPC Duke Primate Centre, Durham, North Carolina, USA

MNHN Muséum national d'Histoire naturelle, Paris, France

NAP Napak locality, Uganda

NHMUK Natural History Museum, London, United Kingdom

UM Uganda Museum, Kampala, Uganda

WUSC WUS corresponds to localities along the Gebel Zelten scarp (Harris 1973) and C probably refers to unit $\mathrm{C}$

\section{Geological setting}

The Moghara area (also known in the literature as Moghra or incorrectly as Wadi Moghara) is located in the northern Western Desert, south of El Alamein, Egypt. The exposed lower Miocene Moghara Formation consists of a thickness of about $400 \mathrm{~m}$ of siliciclastic sediments (Abdel Gawad 2011, Abdel Gawad et al. 2012, Hassan et al. 2012, Hassan 2013).

The Moghara Formation is best exposed in the northeastern escarpment of the Qattara Depression and it dips northward at a few degrees. Hassan et al. (2012) depicted the Moghara Formation as a sandy estuarine complex containing a succession of stratigraphic units that signify repeated transgressive to regressive shoreline movements across the early Miocene coastal landscape. The palaeoenvironment of Moghara has been indicated to be a series of estuarine units stacked in a net transgressive stratigraphy (tide dominated estuary environment) (Abdel Gawad 2011, Hassan 2013).

Vertebrate fossils have been described from four stratigraphic horizons located on the basal surface of units II, VI, VIII, and X, and the fossil horizons are known as F1, F2, F3, and F4, respectively (Abdel Gawad et al. 2010, Abdel Gawad 2011, Abdel Gawad et al. 2012). Each horizon represents an erosional lag surface comprised of mud clasts associated with coprolites and silicified wood.

The ${ }^{87} \mathrm{Sr} /{ }^{86} \mathrm{Sr}$ analyses revealed that the Moghara sequence ranges in age from 21 Ma near the base of the section to around $17 \mathrm{Ma}$ at its top. Most of the specimens from the CUWM collection were collected from the lower to middle part of the section, ranging in age from 19.6 to $18.2 \mathrm{Ma}$, however, a few specimens were collected from deposits approaching $17 \mathrm{Ma}$ (Hassan 2013, Morlo et al. 2019, Georgialis et al. 2020).

The presence of fossil vertebrates at Moghara has been known since the late $19^{\text {th }}$ Century (Jennings-Bramley 1897 , Andrews 1899, 1900, Blanckenhorn 1900, 1901, Fourtau 1918, 1920, Abdel Gawad 2011; see also Georgialis et al. 2020). The Moghara fauna includes a high diversity and abundance of early Miocene mammals, reptiles, birds and fishes. It is characterised by excellent preservation of the fossils.

\section{Systematic palaeontology}

\author{
Order Artiodactyla Owen, 1848 \\ Superfamily Suoidea Gray, 1821 \\ Family Sanitheriidae Simpson, 1945 \\ Genus Diamantohyus Stromer, 1922
}

Type species. Diamantohyus africanus Stromer, 1922.

Diamantohyus africanus STROMER, 1922

Holotype: BSPG $1926 \mathrm{X}$, right maxilla with P3/, M1/-M2/, currently lost (Gertrud Rößner, personal communication 2009). Figured in Stromer (1926: pl. 40, fig. 17); also figured in Pickford (1984: fig. 1).

D i g n o s is. Differs from species of Sanitherium in having less molarized premolars, and in having anterior and postero-lingual cusps less developed; P4/ with two main cusps and two subsidiary ones; metastylid prominent on unworn specimens; $\mathrm{m} / 1-\mathrm{m} / 3 \mathrm{ca} .40 \mathrm{~mm}$ long (range 37.5 to $42.5 \mathrm{~mm}$ ) (after Pickford 1984). Smaller than Diamantohyus nadirus (WiLKINSON, 1976).

Type locality and age. Langental, Namibia, early Miocene.

New material. CUWM 239, left m/3; CUWM 261, right mandible fragment with damaged $\mathrm{m} / 2-\mathrm{m} / 3$; CUWM 360 , right mandible fragment and associated $\mathrm{m} / 3$.

D e s c r i p t i o n. CUWM 40 (palate), CUWM 57 (m/3), CUWM 59 (M2/), CUWM 63 (left juvenile mandible), CUWM 106 (left adult mandible), CUWM 121 (mandible with $\mathrm{m} / 3$ ) and CUWM $134(\mathrm{~m} / 1)$ have already been described (Tab. 1) (Pickford et al. 2010). They are re-illustrated in stereo for convenience (Text-figs 1-6) and measurements are provided in Table 2 . 
Table 1. Old and new catalogue numbers of Diamantohyus africanus from Moghara, Egypt.

\begin{tabular}{|l|l|l|}
\hline \multicolumn{1}{|c|}{ Old catalogue number } & \multicolumn{1}{|c|}{ New catalogue number } & \multicolumn{1}{c|}{ Specimen } \\
\hline WM 05-50 & CUWM 40 & Palate with both cheek tooth rows \\
\hline WM 05-48 (DEC06-025) & CUWM 57 & Right $\mathrm{m} / 3$ \\
\hline WM 05-21 & CUWM 59 & Right M2/ \\
\hline WM 06-14 & CUWM 63 & Left mandible d/4-m/2 \\
\hline WM 06-49 & CUWM 106 & Left mandible, $\mathrm{p} / 4-\mathrm{m} / 3$ \\
\hline WM 06-55 & CUWM 121 & Right mandible, $\mathrm{m} / 3$ \\
\hline WM DEC06-11 & CUWM 134 & Right $\mathrm{m} / 1$ \\
\hline 97-697 & CGM 12612 & Right mandible, $\mathrm{m} / 2-\mathrm{m} / 3$ \\
\hline
\end{tabular}

CUWM 239 is a left $\mathrm{m} / 3$ in light wear (Text-fig. 7). Part of the protoconid is missing and there is a crack across the metaconid, but otherwise the specimen is well preserved. It has a small anterior accessory cusplet and larger median and posterior accessory cusplets. The talonid is comprised of a single cuspid which is in line with the protoconid and hypoconid and it has lingual and buccal precristids. The buccal cingulum is well developed and beaded.

Mandible CUWM 261 (Text-fig. 8) is a right mandible preserved from the symphysis to the $\mathrm{m} / 3$ but the premolars and first molar are missing and $m / 2-m / 3$ are damaged. The rear of the symphysis is beneath the $\mathrm{p} / 3$ and the mental foramen is in the lower third of the body of the mandible beneath the front of $m / 1$. The body is deep beneath the $m / 3$ but shallows markedly anteriorly.

CUWM 360 comprises an edentulous mandible fragment with the roots of $\mathrm{m} / 1$ and $\mathrm{m} / 2$ and the anterior alveoli of $\mathrm{m} / 3$, as well as an isolated $\mathrm{m} / 3$ missing part of the anterior lophid, found close by (Text-fig. 9). The $\mathrm{m} / 3$ is unworn and shows well the beaded buccal cingulum.

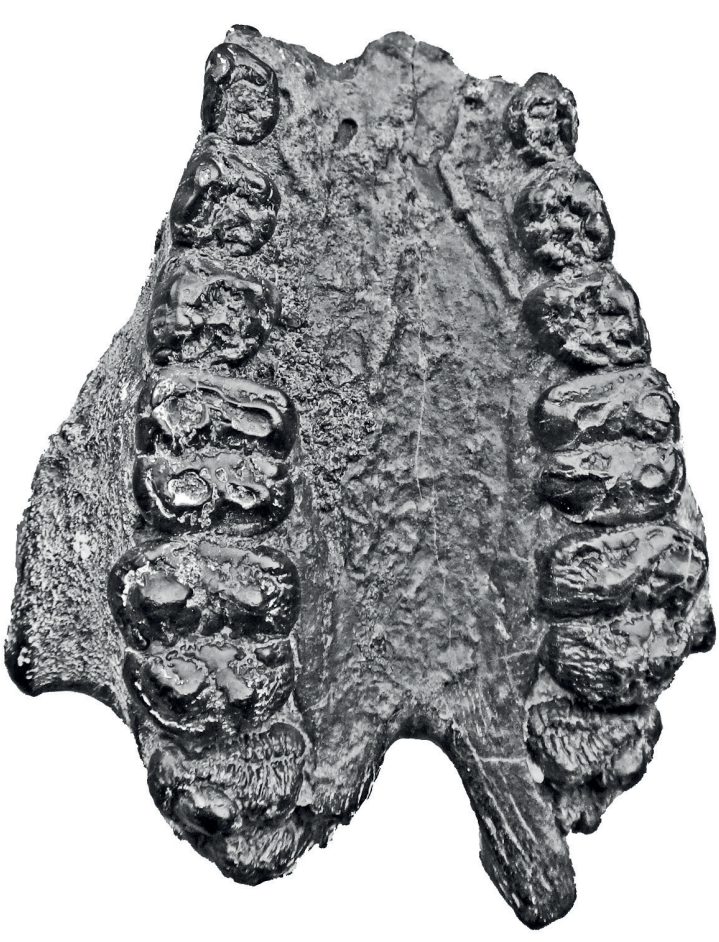

Family Suidae GraY, 1821

Subfamily Kubanochoerinae GabUNIA, 1958

Genus Nguruwe PickFord, 1986

Ty pe s pecies. Hyotherium kijivium WILKInson, 1976.

Diagnosis. A small genus of Kubanochoerinae in which the I1/ is labio-lingually compressed, not meeting interproximally; P4/ with two main cusps and complete cingulum; molars with thick enamel, inflated main cusps, closed lingual notches; simple talon(id) in $\mathrm{M} 3 /$ and $\mathrm{m} / 3$; occlusal outline of $\mathrm{m} / 3$ symmetrical; $\mathrm{p} / 3$ with wide distal lingual cingular cusp or platform; $\mathrm{p} / 4$ with 'Innenhügel' almost completely suppressed; d/4 labio-lingually inflated; lower canine scrofic; upper canine with dorsal cement cover (from Pickford 1986).

\section{Nguruwe kijivium (WILKInson, 1976)}

H o 1 o t y p e. UM NAP I'64, left maxilla fragment with M1/-M3/ (Wilkinson 1976: pl. 2, fig. g).

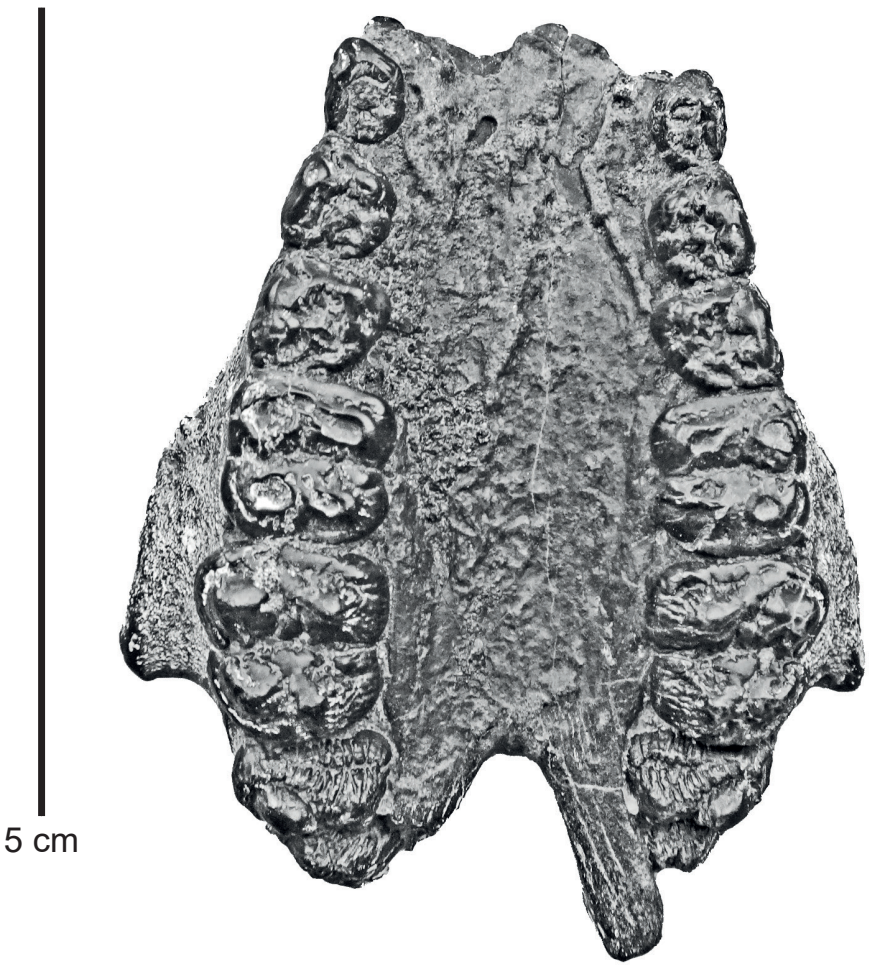

Text-fig. 1. CUWM 40, palate of Diamantohyus africanus from Moghara, Egypt, stereo occlusal view. 

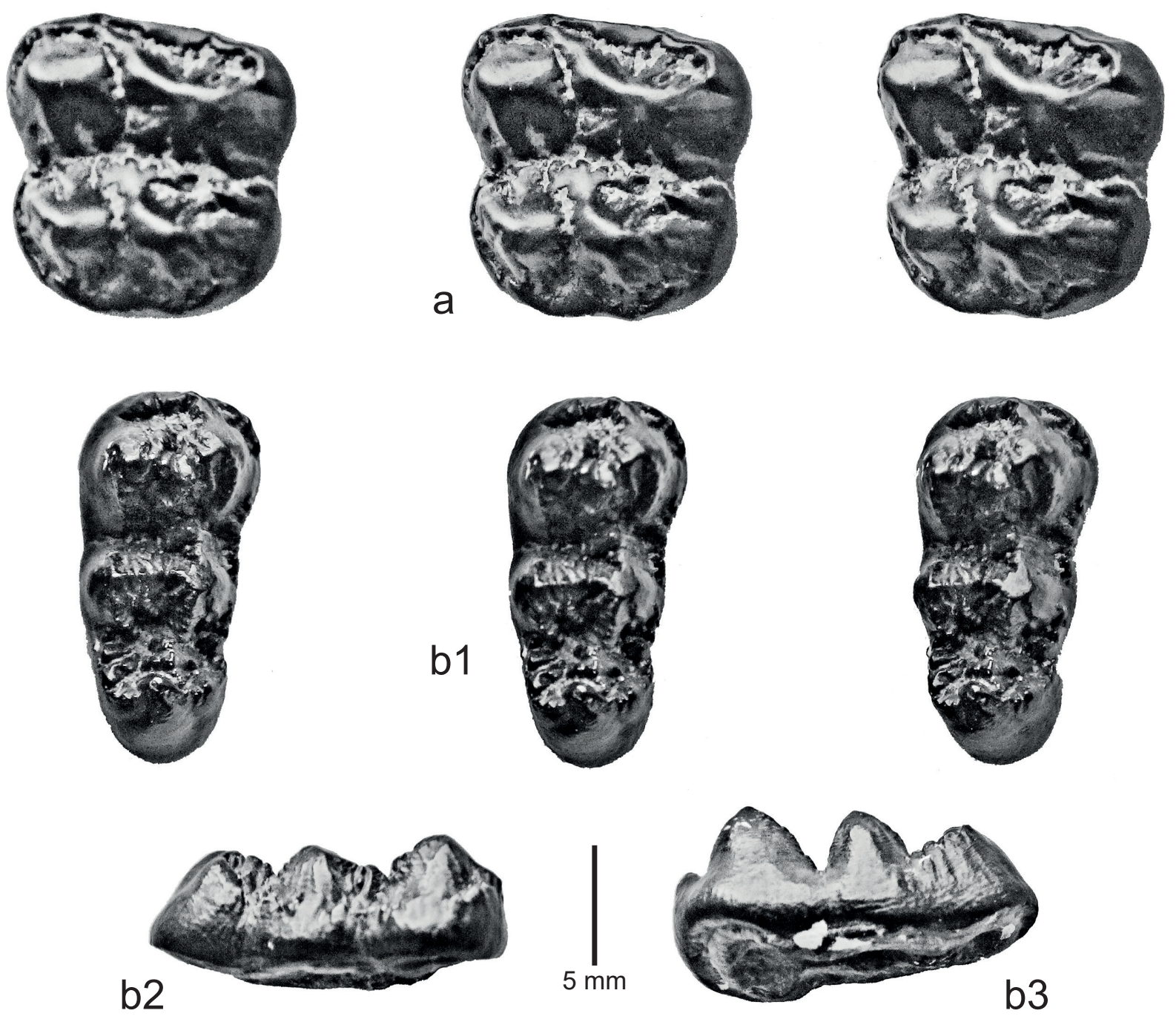

Text-fig. 2. Diamantohyus africanus from Moghara, Egypt. a: CUWM 59, right upper molar, stereo occlusal view; b: CUWM 57, right $\mathrm{m} / 3$, b1 - stereo occlusal views, b2 - buccal view, b3 - lingual view.

Diagnosis. As for the genus; length $\mathrm{m} / 1-\mathrm{m} / 3$ ca. $43 \mathrm{~mm}, \mathrm{M} 1 /-\mathrm{M} 3 /$ ca. $42 \mathrm{~mm}$ (from Pickford and Tsujikawa 2019). Larger than Nguruwe namibensis (Pickford 1986).

Type locality and age. Napak I, Uganda, early Miocene (East African Faunal Set I), ca. 19-20 Ma.

Description. The $\mathrm{m} / 3$ of Nguruwe kijivium from Moghara (CUWM 68) was described by Pickford et al. (2010) under the field number WM DEC06-10. It is reillustrated in stereo for convenience (Text-fig. 10).

Discussion. No new fossils of Nguruwe kijivium have been found at Moghara. This species is known to span the period ca. $20 \mathrm{Ma}$ (Napak, Uganda - Pickford and Tsujikawa 2019) to ca. 17.5 Ma (Arrisdrift, Namibia Pickford 1995).

\section{Genus Libycochoerus Arambourg, 1961} 1961.

\section{Libycochoerus massai ARAMbourg, 1961}

H o 1 o t y p e. Left mandible with p/2-m/3, No. 1961-5-8 MNHN Paris.

Diagn osis. Large kubanochoere, about $10-20 \%$ smaller than Kubanochoerus robustus; upper molar series about $100 \mathrm{~mm}$ long (Pickford 1986). Libycochoerus massai (M1/-M3/ ca. $100 \mathrm{~mm}$ long) is much larger than Kenyasus anchidens (M1/-M3/ ca. $70 \mathrm{~mm}$ long) and Libycochoerus jeanneli (M1/-M3/ ca. 73 mm long) (Pickford and Tsujikawa 2019).

Type locality and age. Gebel Zelten, Libya, terminal early Miocene to basal middle Miocene.

Material from Moghara. CGM 94-138, right mandible fragment containing $\mathrm{p} / 4-\mathrm{m} / 3$ (Tab. 3); CUWM 132 (field number WM DEC06-09) partial right M3/; DPC 17744 canine and DPC 14565 canine are provisionally referred to this species.

Remarks. A right talus (CGM 30791), previously thought to have been collected at Moghara, is in fact from 

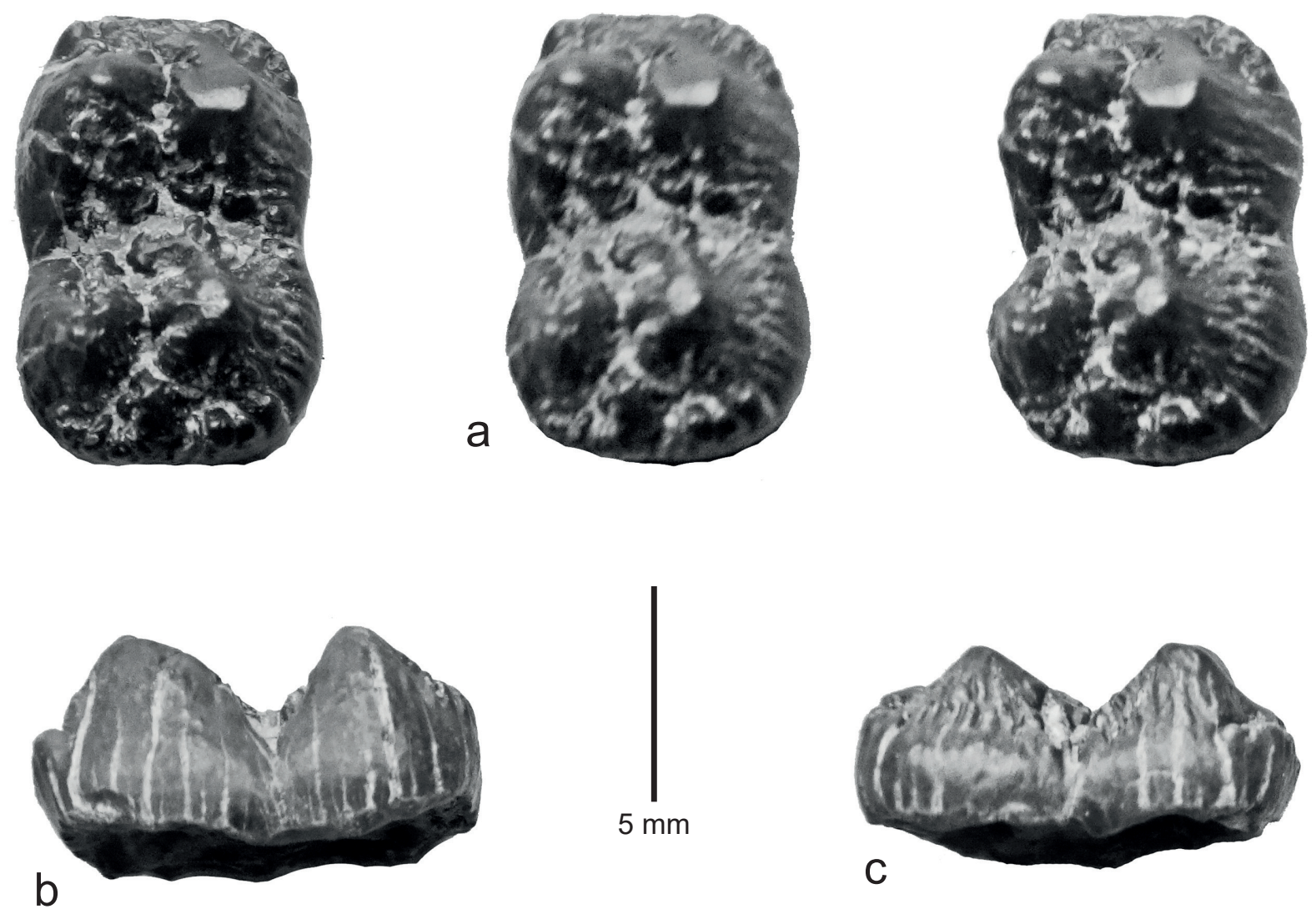

Text-fig. 3. CUWM 134, right lower molar of Diamantohyus africanus from Moghara, Egypt. a: stereo occlusal view; b: lingual view; c: buccal view.
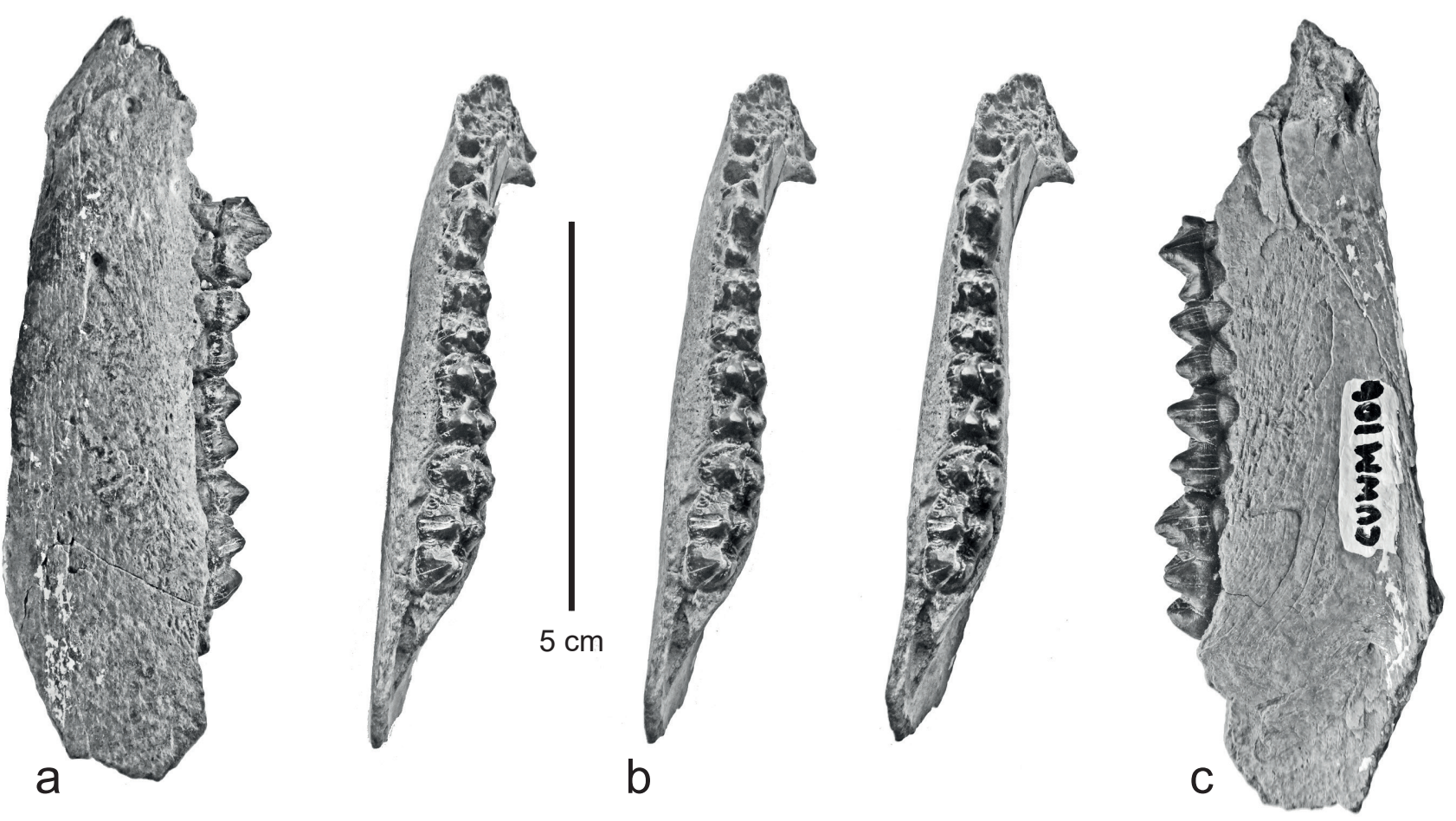

Text-fig. 4. CUWM 106, left mandible with p/4-m/3 of Diamantohyus africanus from Moghara, Egypt. a: buccal view; b: stereo occlusal views; c: lingual view.

Wadi Natrun, a late Miocene site, and is thus more likely to belong to Sivachoerus syrticus LeONARDI, 1954, than to Libycochoerus massai.
De s c ription. The mandible CGM 94-138 is poorly preserved, but retains four teeth (Text-fig. 11). The $\mathrm{p} / 4$ is missing a small section at the mesial end, but is otherwise 

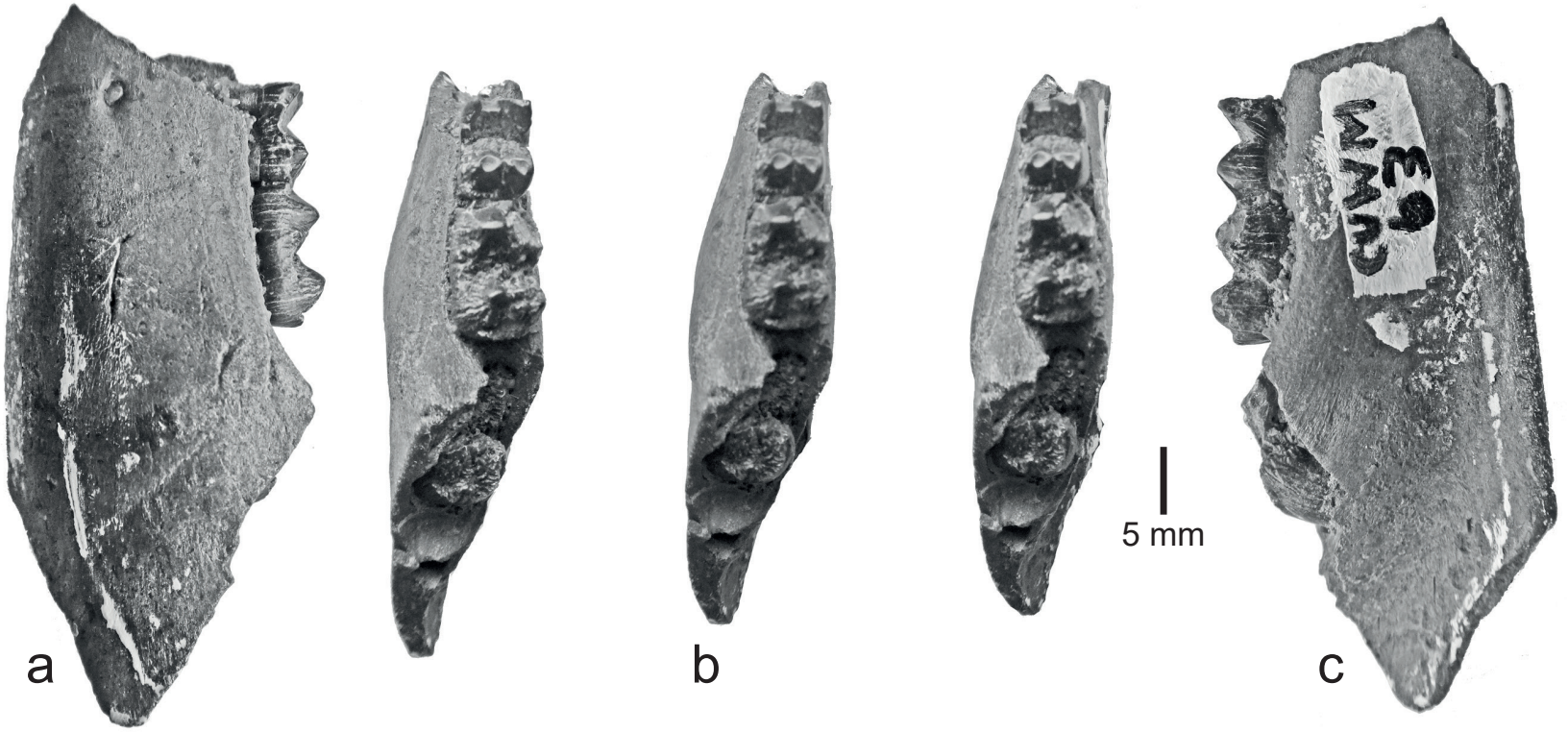

Text-fig. 5. CUWM 63, left mandible with d/4-m/2 of Diamantohyus africanus from Moghara, Egypt. a: buccal view; b: stereo occlusal views; c: lingual view.
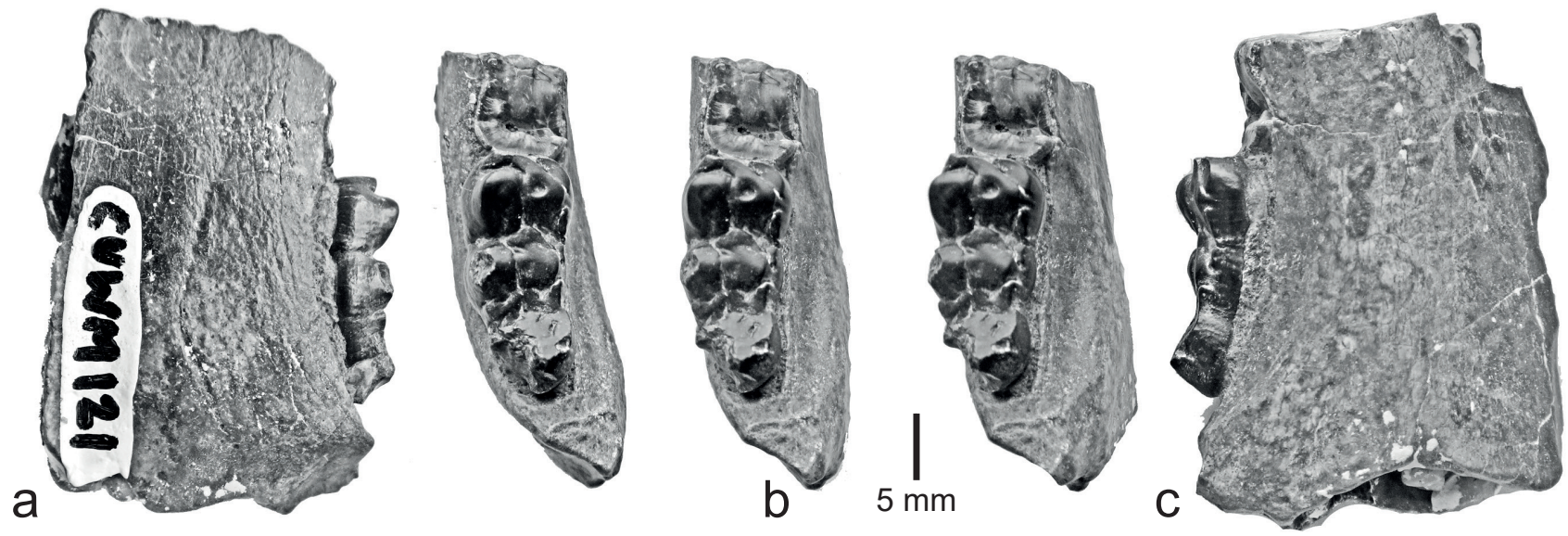

Text-fig. 6. CUWM 121, right mandible with $\mathrm{m} / 3$ of Diamantohyus africanus from Moghara, Egypt. a: lingual view; b: stereo occlusal views; c: buccal view.
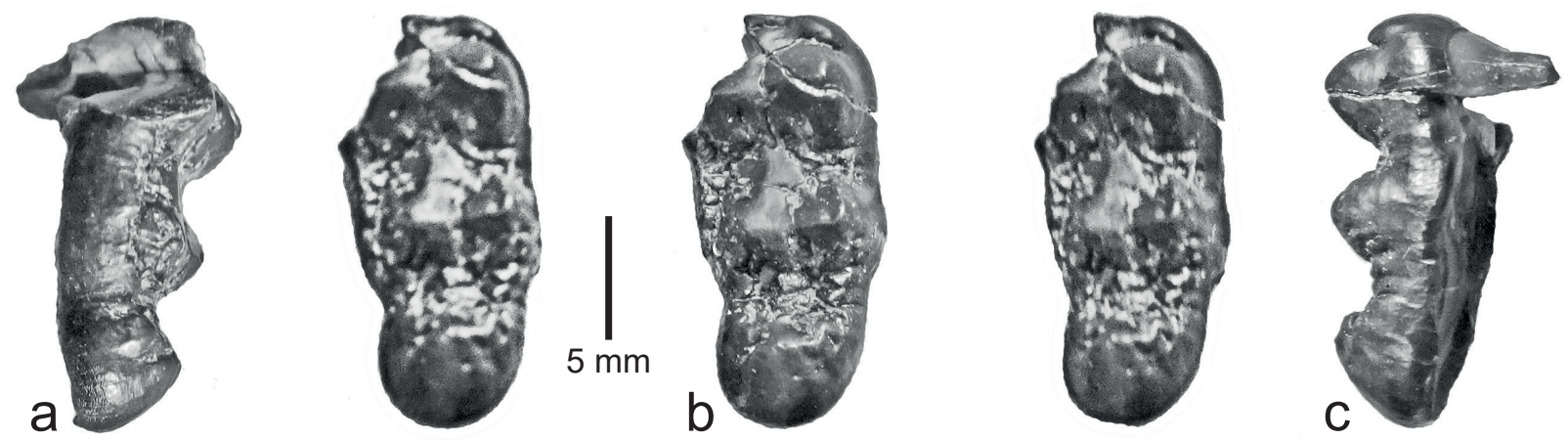

Text-fig. 7. CUWM 239, left $\mathrm{m} / 3$ of Diamantohyus africanus from Moghara, Egypt. a: buccal view; b: stereo occlusal views; c: lingual view.

in good condition. The protoconid is tall and is positioned above the gap between the two roots. The metaconid is closely applied to the protoconid but is small, as is usually the case in kubanochoeres, its presence being shown by a shallow sulcus on the mesial aspect of the main cusp. The posterior accessory cusplet is about half the height of the main cusp, and distally it has crests that descend either side to the distal cingulum. 

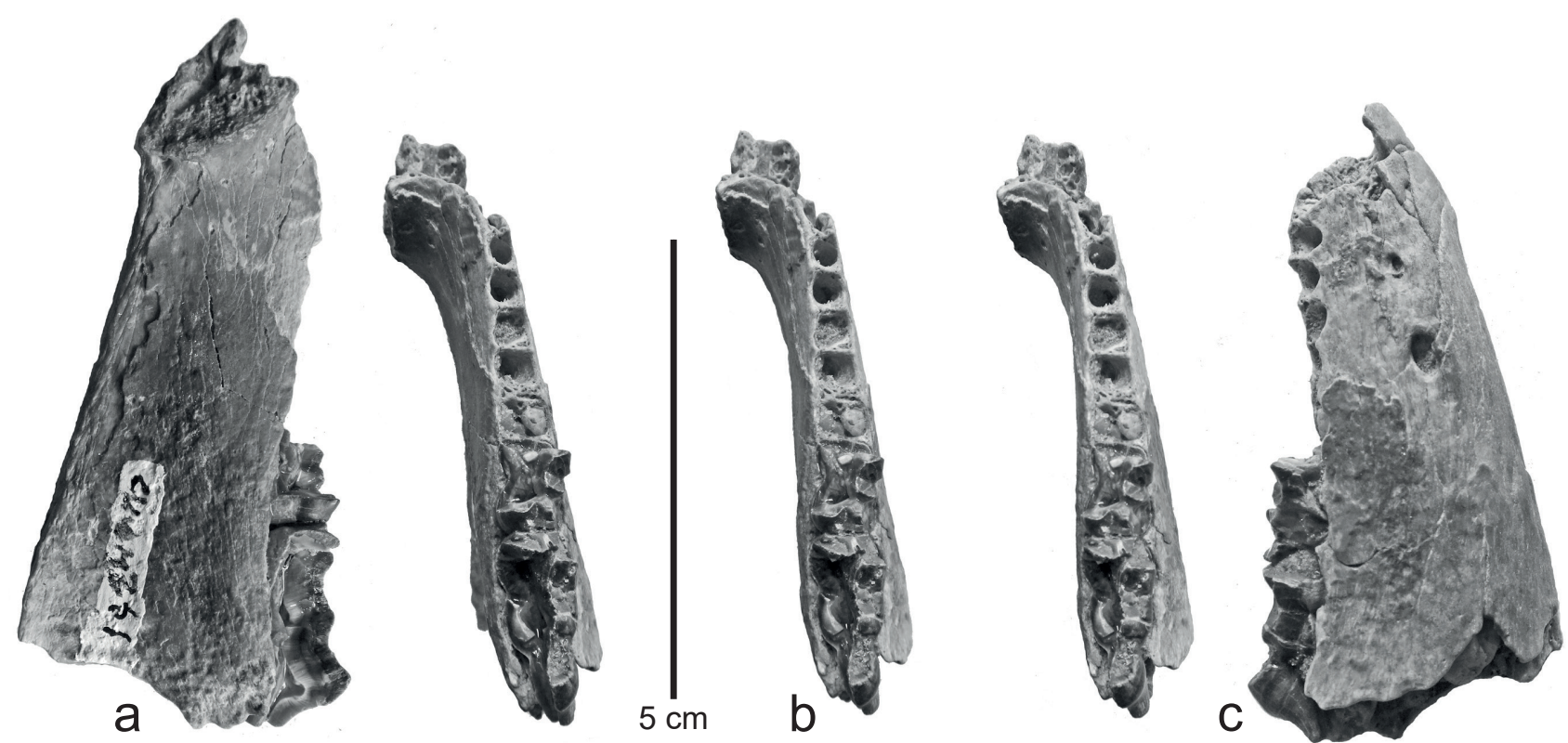

Text-fig. 8. CUWM 261, right mandible with damaged m/2-m/3 of Diamantohyus africanus from Moghara, Egypt. a: lingual view; b: stereo occlusal views; c: buccal view.

The $\mathrm{m} / 1$ has four main cusps arranged in two pairs, plus a weak anterior accessory cusplet and strong median and posterior accessory cusplets. The furchen in the main cusps are shallow. There is a cingular remnant at the buccal end of the median transverse valley. The $\mathrm{m} / 2$ is of similar construction to the $\mathrm{m} / 1$. It is missing the lingual part of the metaconid. The $\mathrm{m} / 3$ has lost the enamel of the mesial lophid, but the second lophid and the talonid are well preserved. The furchen are shallow and the talonid complex is separated from the second lophid by the posterior accessory cusplet. The talonid is comprised of a single, centrally positioned main cusp which has beaded crests leading anteriorly on its lingual and buccal sides which terminate at the distal base of the hypoconid and entoconid respectively.

The upper third molar from Moghara (Text-fig. 12) was described previously by Pickford et al. (2010) so it is not necessary to repeat it. However, stereo images are provided for clarification.

The $\mathrm{p} / 4, \mathrm{~m} / 1$, and $\mathrm{m} / 2$ in the mandible from Moghara are somewhat smaller than any of the specimens from Gebel Zelten, but the $\mathrm{m} / 3$ and $\mathrm{M} 3$ / plot within the lower part of the range of variation of the Libyan sample (Text-fig. 13). The mandible and the isolated $\mathrm{M} 3$ / are therefore interpreted to belong to a small individual of the species Libycochoerus massai rather than to a hitherto unidentified species. In particular the length dimensions of the anterior teeth had to be estimated due to their damaged condition.

\section{Genus Kubwachoerus Pickford et Tsujikawa, 2019}

Type species. Bunolistriodon khinzikebirus WILKINSON, 1976.

Genus diagnosis. Large to gigantic kubanochoerine suids with marked buccal and lingual flare in the upper and lower molars, relatively weak furrowing in the molar enamel, relatively short, but massive, tightly curved upper male canines which are much narrower in their radicular part than in the emergent part, verrucosic lower canines.

Note. In a recent revision of the subfamily Kubanochoerinae, Pickford and Tsujikawa (2019) defined a new genus, Kubwachoerus, on the basis of its generally large dimensions and the broader molars that it possesses when compared with those of Kubanochoerus and Libycochoerus.

\section{Kubwachoerus khinzikebirus (WILKInson, 1976)}

H o lo t y p e. BU 6416-82 a-e, right $\mathrm{p} / 2-\mathrm{p} / 4$, fragment of $\mathrm{m} / 2$, complete $\mathrm{m} / 3$ (cast in NHMUK M 32995).

$\mathrm{P}$ a r a t y $\mathrm{p} \mathrm{e}$. BU 6242-92, cast of right maxilla containing $\mathrm{P} 1 /-\mathrm{M} 3$ / (original fossil is curated at Bristol University).

Diagnosis. Very large kubanochoere about 10 to $20 \%$ larger than Kubanochoerus robustus; M1/-M3/ ca. $135 \mathrm{~mm}$ long, $\mathrm{m} / 1-\mathrm{m} / 3 \mathrm{ca} .142 \mathrm{~mm}$ long (from Pickford and Tsujikawa 2019). Smaller than Kubwachoerus nyakachensis PICKFORD et TsuJIKAWA, 2019, and larger than Kubwachoerus marymuunguae (VAN DER MADE, 1996).

Type locality and age. Gebel Zelten, Libya, basal middle Miocene, ca. $16 \mathrm{Ma}$.

Distribution. Libya (Gebel Zelten), Kenya (Maboko, Majiwa, Kipsaraman, Cheparawa), Turkey (Inönü), possibly Saudi Arabia (As Sarrar, Tayma), possibly Uganda (Napak XXXII).

Description. The mandible from Gebel Zelten (ATH 6C 1) is important even though it retains no tooth crowns, because it is undistorted and preserves both bodies and the symphysis, lacking only the dentition and the upper parts of the ascending rami (Text-figs 14-15).

The symphysis is relatively narrow, not splayed out as in Listriodontinae, and the lower canine alveoli show a verrucosic section. The canines are steeply inserted in the jaw with only slight lateral splay. The incisor alveoli are 

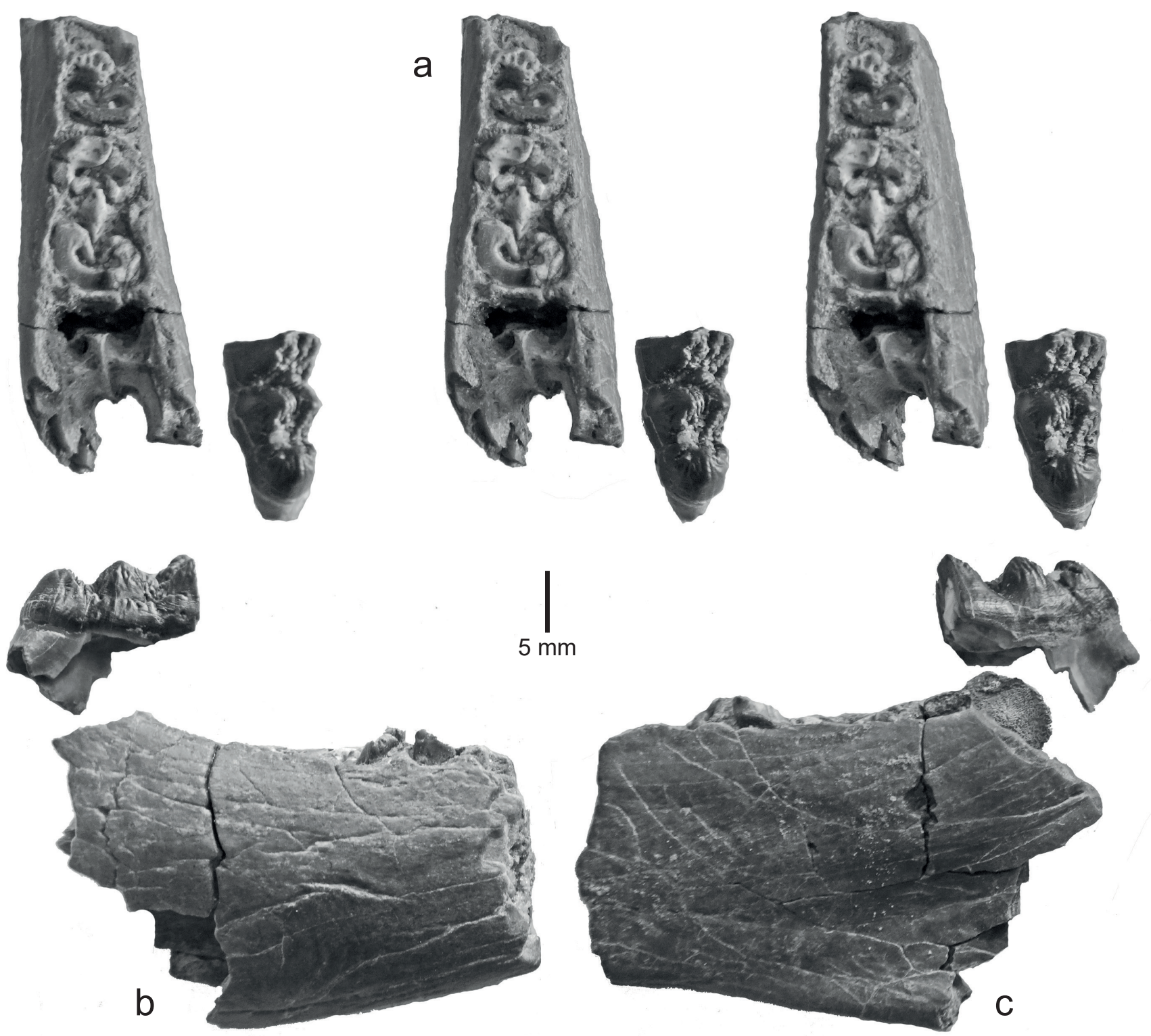

Text-fig. 9. CUWM 360, right mandible fragment and associated m/3 of Diamantohyus africanus from Moghara, Egypt. a: stereo occlusal views; b: buccal view; c: lingual view.

Table 2. Measurements (in $\mathrm{mm}$ ) of newly discovered teeth of Diamantohyus africanus from Moghara, Egypt (e - estimated measurement).

\begin{tabular}{|l|c|c|c|}
\hline Catalogue no. & Tooth & Mesio-distal length & Bucco-lingual breadth \\
\hline CUWM 261 & $\mathrm{~m} / 2 \mathrm{rt}$ & 9.0 & - \\
\hline CUWM 261 & $\mathrm{~m} / 3 \mathrm{rt}$ & 17.8 & 8.5 \\
\hline CUWM 360 & $\mathrm{~m} / 3 \mathrm{rt}$ & $19 \mathrm{e}$ & 9.9 \\
\hline CUWM 239 & $\mathrm{~m} / 3 \mathrm{lt}$ & 17.6 & 8.4 \\
\hline
\end{tabular}

close together and the $i / 3$ is close to the canine. There is a short diastema between the lower canine and the $\mathrm{p} / 1$, and a second one between the $\mathrm{p} / 1$ and $\mathrm{p} / 2$, the rest of the cheek teeth being in contact with one another. The root of the ascending ramus sweeps upwards at the rear of the $m / 3$. The body of the mandible is shallow, unlike the uniformly deeper jaws that occur in Listriodontinae (Pickford and Tsujikawa 2019). The masseteric fossa is vast, its antero-posterior length almost
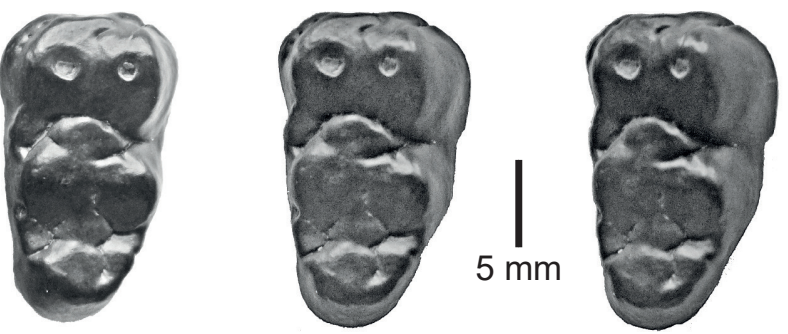

Text-fig. 10. CUWM 68 , left $\mathrm{m} / 3$ of Nguruwe kijivium from Moghara, Egypt.

equalling the distance between the $\mathrm{p} / 2$ and the $\mathrm{m} / 3$. The angle of the jaw is slightly behind the level of the rear of $\mathrm{m} / 3$ and the ventral margin descends gently distally before curving upwards and backwards and then upwards and forwards towards the condyles which are missing in this specimen.

There are two moderately large mental foramina beneath the front of the $\mathrm{p} / 2$ at about half the height of the ramus, and there are small foramina beneath the $p / 3$ and the $p / 4$. 

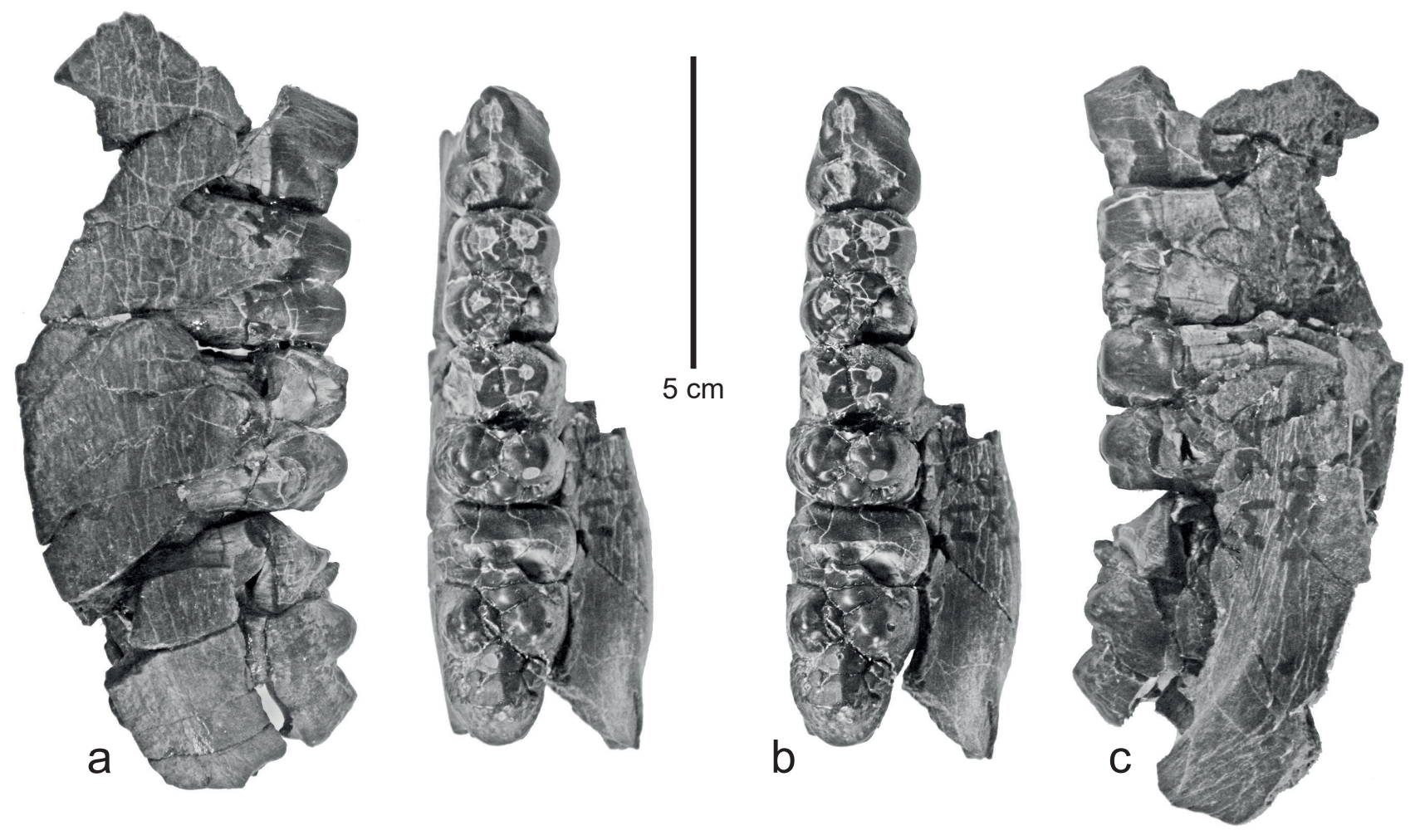

Text-fig. 11. CGM 94-138, right mandible fragment containing p/4-m/3 of Libycochoerus massai from Moghara, Egypt. a: lingual view; b: stereo occlusal view; c: buccal view.
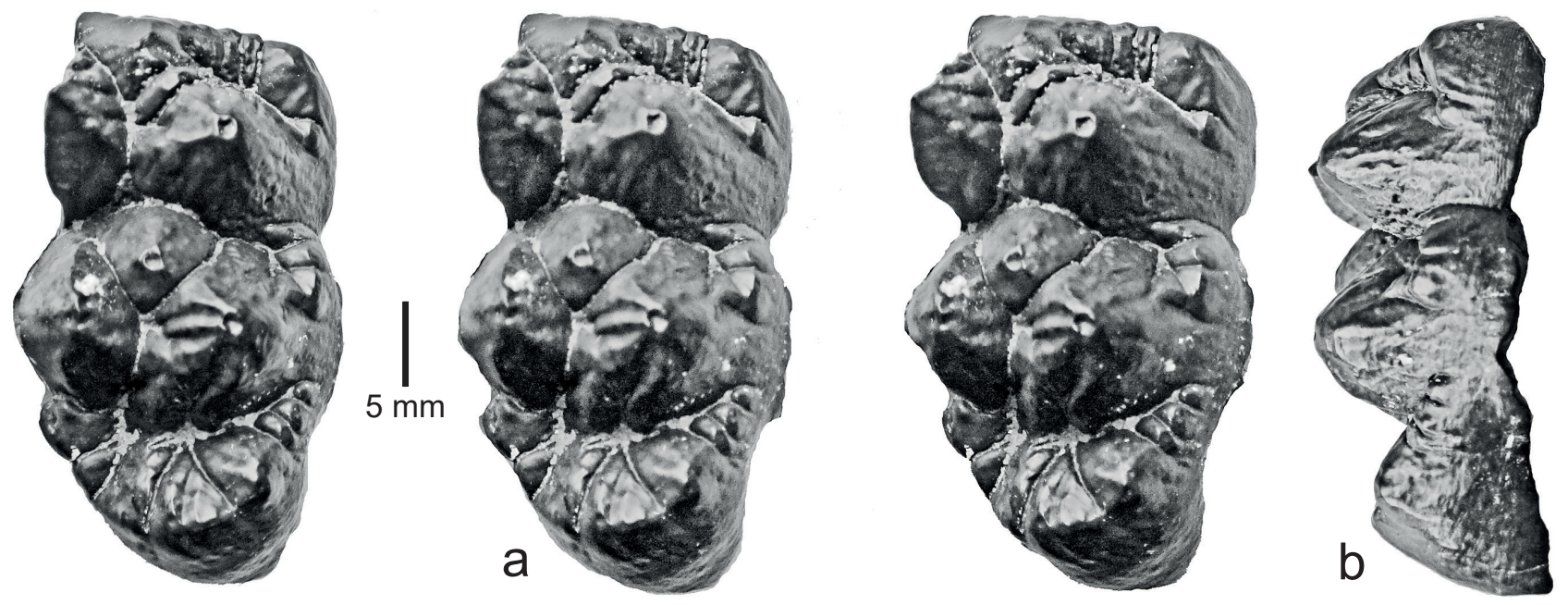

Text-fig. 12. CUWM 132, right M3/ of Libycochoerus massai from Moghara, Egypt. a: stereo occlusal views; b: lingual view.

Table 3. Measurements (in mm) of teeth of Libycochoerus massai from Moghara, Egypt (+ the measurement provided is a minimum because the tooth is damaged).

\begin{tabular}{|l|c|c|c|}
\hline \multicolumn{1}{|c|}{ Catalogue no. } & Tooth & Mesio-distal length & Bucco-lingual breadth \\
\hline CGM 94-138 & $\mathrm{p} / 4 \mathrm{rt}$ & $21.0+$ & 19.4 \\
\hline CGM 94-138 & $\mathrm{m} / 1 \mathrm{rt}$ & $21.8+$ & 18.7 \\
\hline CGM 94-138 & $\mathrm{m} / 2 \mathrm{rt}$ & $25.7+$ & $20.9+$ \\
\hline CGM 94-138 & $\mathrm{m} / 3 \mathrm{rt}$ & 44.0 & 26.0 \\
\hline CUWM 132 (WM Dec-06-09) & $\mathrm{M} 3 / \mathrm{rt}$ & 33.4 & 26.0 \\
\hline
\end{tabular}



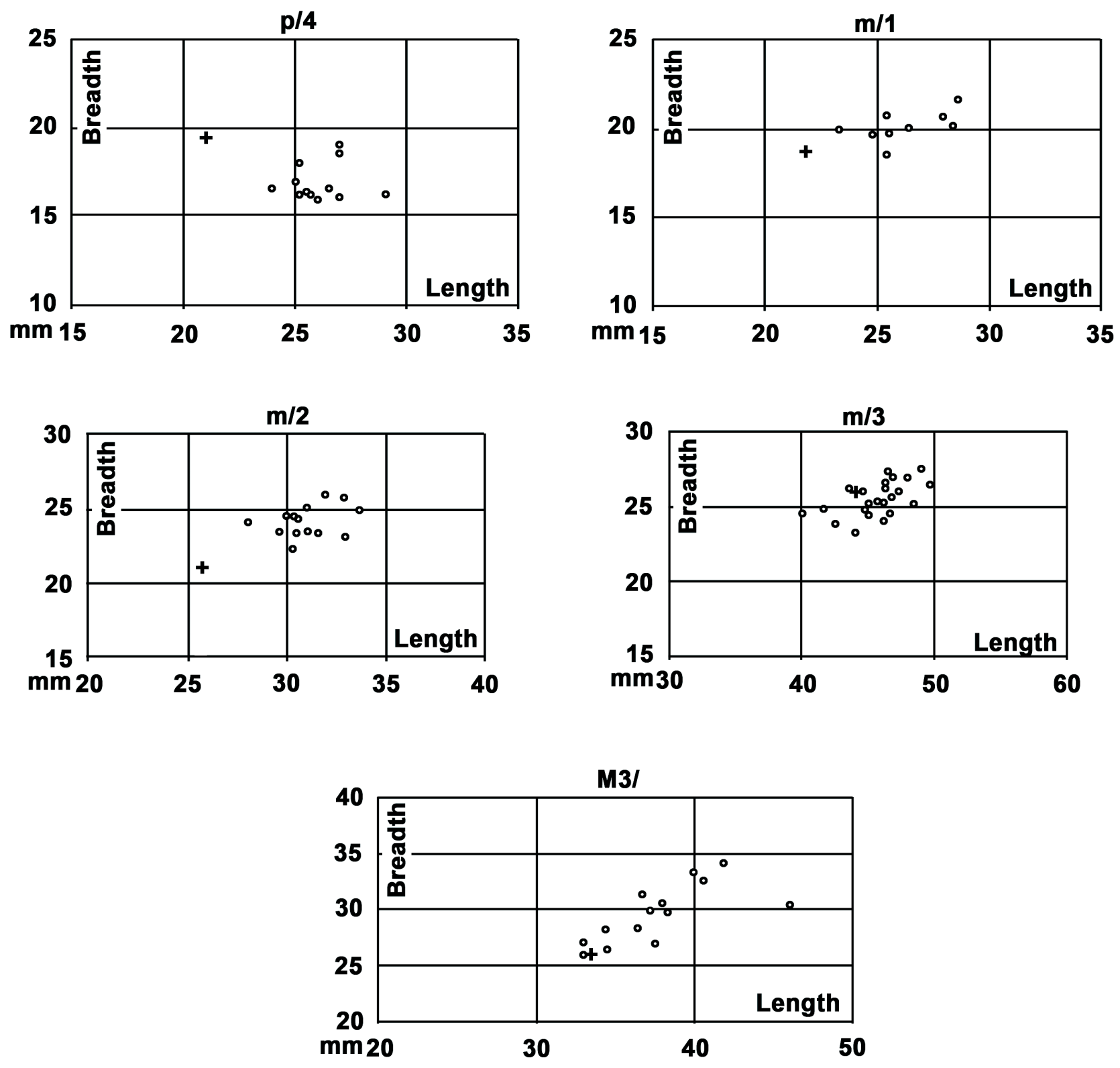

Text-fig. 13. Bivariate plots of teeth of Libycochoerus massai from Gebel Zelten (circles) and Moghara (+ sign).

The rear of the symphysis is beneath the middle of the $\mathrm{p} / 3$. In ventral view, the symphysis shows two prominent foramina beneath the alveoli of $i / 2$, and smaller ones beneath the alveoli of $\mathrm{i} / 3$.

Measurements of the teeth have been estimated from the roots or the alveoli (Tab. 4). Pickford (2006) provided measurements of the lower canine and the $\mathrm{m} / 2$ which were taken by D. Soria.

The snout (WUSC 4C 33) has already been described by Pickford (2006). It is re-illustrated herein (Text-fig. 16), because the previous images were obtained from a video which resulted in rather low resolution figures. The small dimensions of the upper canine alveoli indicate that this individual was probably a female.

\section{Discussion}

The previous record of suoids from Moghara indicated correlation to the late early Miocene (Pickford et al. 2010).
The taxa recognised at the site were Diamantohyus africanus, Nguruwe kijivium, Libycochoerus sp. (size of L. anchidens and L. jeanneli) and Libycochoerus massai (Text-fig. 17).

Diamantohyus africanus is relatively common at the site (16+ specimens), but suid fossils are rare, Nguruwe kijivium being represented by only three specimens, Libycochoerus anchidens or L. jeanneli by one specimen, and Libycochoerus massai by three isolated teeth, two of which are canines. Thus a mandible with four teeth of the last named species is a significant addition to the sample.

The suoids from Gebel Zelten, Libya, include two of the species recorded from Moghara (Diamantohyus africanus and Libycochoerus massai) but in addition Gebel Zelten has yielded several fossils of a much larger suid, Kubwachoerus khinzikebirus which, up to now, has not been recorded from Moghara. On this basis it is inferred that some of the strata at Moghara could have accumulated at the same time as some of the deposits at Gebel Zelten, but that sediments continued to be deposited at the latter site after deposition at 


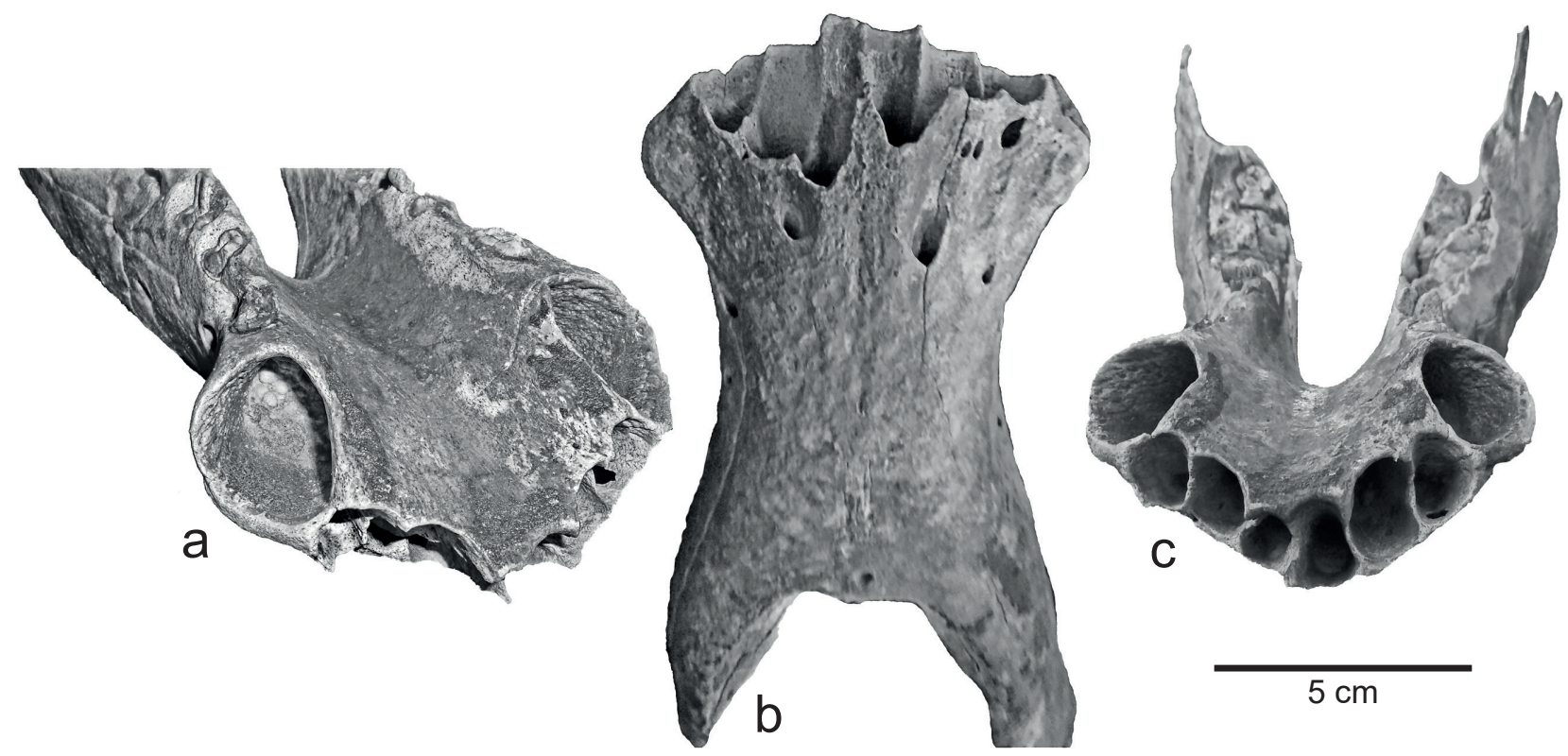

Text-fig. 14. ACH 6C 1, mandible of Kubwachoerus khinzikebirus from Gebel Zelten, Libya. a: oblique anterior view to show alveolus of right lower canine; b: oblique ventral view of symphysis; $c$ : anterior view to show incisor and canine alveoli.

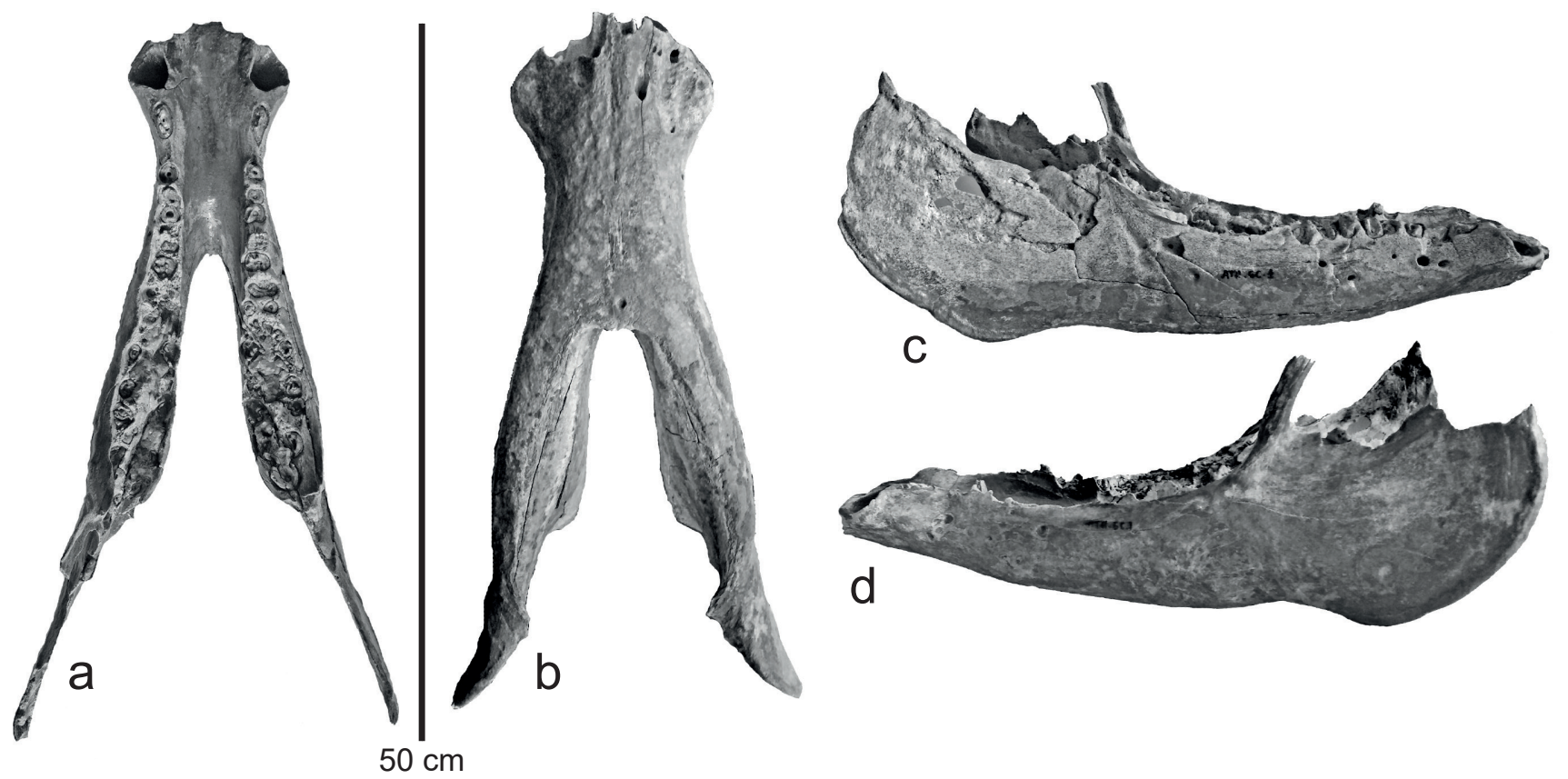

Text-fig. 15. ACH 6C 1, mandible of Kubwachoerus khinzikebirus from Gebel Zelten, Libya. a: occlusal view; b: ventral view; c: right lateral view; d: left lateral view.

Moghara had ceased. Thus, whereas the Moghara succession is estimated to span the period from ca. 19.5 to $16.5 \mathrm{Ma}$ (closest to Faunal Set PII and PIIIa), the succession at Gebel Zelten is inferred to extend upwards in time to ca. $15 \mathrm{Ma}$ or perhaps even younger (14.5 Ma) (Faunal Sets PIIIa-PIIIb) (Pickford 2001, Pickford and Tsujikawa 2019).

The fossil micromammals from Gebel Zelten indicate the presence of sediments of middle Miocene age (Wessels et al. 2003). These authors estimated that the base of the succession at Gebel Zelten was about 19.5 Ma, but this was based on the presence of Kenyalagomys and Prokanisamys and on the supposed age of Rusinga at 19 Ma (it's age is ca.
17.8 Ma; Drake et al. 1988). The latter genus has not been recorded from the early Miocene of Africa, and the former is known to extend its range upwards into Faunal Set P III. Thus the lowermost strata at Gebel Zelten are likely to be appreciably younger than 19.5 Ma. Herein the base of the succession is estimated to be about $17 \mathrm{Ma}$.

\section{Conclusions}

In January, 2020, several specimens of the sanithere Diamantohyus africanus were collected from Moghara, 

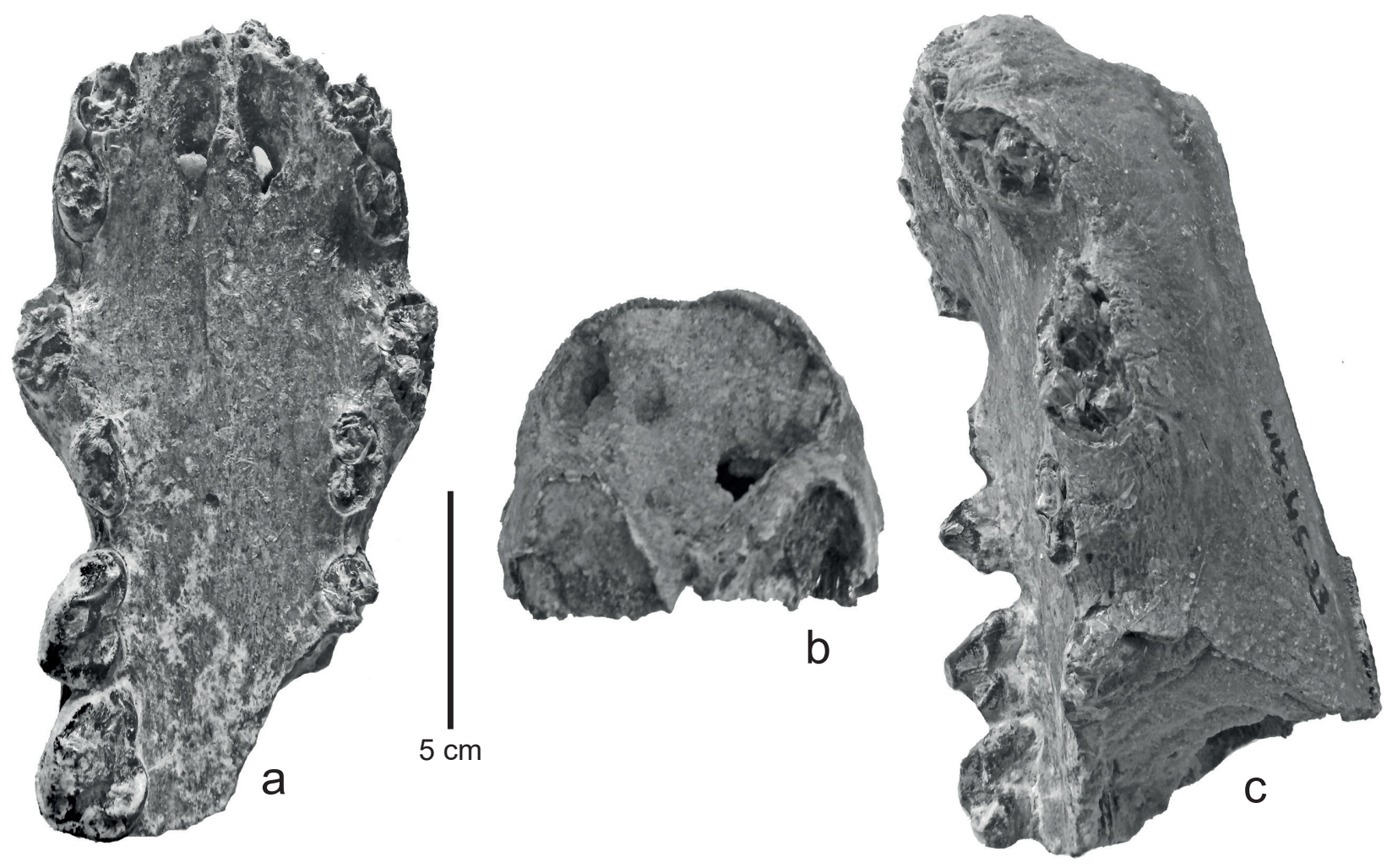

Text-fig. 16. WUSC 4C 33, snout of Kubwachoerus khinzikebirus from Gebel Zelten, Libya. a: palatal view; b: anterior view; c: left lateral view.

Egypt, confirming the relative abundance of this species at the site, in contrast to the rarity of Suidae, of which none were found in 2020. In the Cairo Geological Museum, there is an undescribed partial mandible of a large suid from Moghara, collected in 1994. This mandible retains four teeth and is interpreted to belong to the species Libycochoerus massai, a genus and species first described from Gebel Zelten, Libya (Arambourg 1961). The fossil represents a small individual of the species. This material confirms the presence of the taxon at Moghara, previously inferred to be present on the basis of an isolated $\mathrm{M} 3 /$, two canine fragments and a talus. The last specimen (talus) is transferred to Sivachoerus, because it is now known to have been collected from Wadi Natrun, Egypt (late Miocene) and not from Moghara.

The suoids from Moghara comprise three species of suid (Nguruwe kijivium, Libycochoerus massai, Kubwachoerus khinzikebirus) and one sanithere (Diamantohyus africanus), an assemblage that is typical of late early Miocene and basal middle Miocene times. On the basis of the suoid fauna, the Moghara sedimentary succession is estimated to span the period ca. 19.5 to $16.5 \mathrm{Ma}$, whereas the sequence at Gebel Zelten, Libya, is estimated to extend from ca. $17 \mathrm{Ma}$ to ca. 14.5 Ma.

A huge suid mandible from Gebel Zelten, Libya, adds useful information about the morphology of this bone, indicating that it differs in important ways from the lower jaws of Listriodontinae which have deeper mandibular bodies and more splayed out symphyseal areas in which the lower canines are oriented almost horizontally. It is inferred that Kubanochoerinae originated in Africa from a Palaeochoerinae, whereas Listriodontinae evolved independently in Europe, but also from Palaeochoerinae (Pickford et al. 2020).
Table 4. Measurements (in mm) of the mandible of Kubwachoerus khinzikebirus (ATH 6C 1) from Gebel Zelten, Libya. In brackets are measurements taken by Soria (in Pickford 2006).

\begin{tabular}{|l|c|}
\hline Measurement & mm \\
\hline Labial length lower canine & $38.8(39.0)$ \\
\hline Distal breadth lower canine & $34.0(32.6)$ \\
\hline Length of diastema between $\mathrm{c} / 1$ and $\mathrm{p} / 1$ & 9.7 \\
\hline Length $\mathrm{p} / 1$ & 22.6 \\
\hline Length of diastema between $\mathrm{p} / 1$ and $\mathrm{p} / 2$ & 20.5 \\
\hline Length $\mathrm{p} / 2$ & 30.2 \\
\hline Length $\mathrm{p} / 3$ & 32.1 \\
\hline Length $\mathrm{p} / 4$ & 34.9 \\
\hline Length $\mathrm{m} / 1$ & 32.8 \\
\hline Length $\mathrm{m} / 2$ & $44.1(46.6)$ \\
\hline Length $\mathrm{m} / 3$ & 68.5 \\
\hline Length $\mathrm{m} / 1-\mathrm{m} / 3$ & 137.8 \\
\hline Distance between lateral margins of the $\mathrm{i} / 3$ alveoli & 68.3 \\
\hline Length of symphysis in sagittal plane & 170 \\
\hline Total length of mandible & 495.2 \\
\hline Depth of body beneath $\mathrm{p} / 4$ & 66.7 \\
\hline Depth of body beneath front of $\mathrm{m} / 3$ & 75.3 \\
\hline
\end{tabular}

\section{Acknowledgements}

We thank Moustafa el Bahr, the Chairman of the Egyptian Mineral Resources Authority (EMRA) and Dr. Ali Khyami, the Chief of Mohamed El Hakim (The General Director of the Egyptian Geological Museum) for 


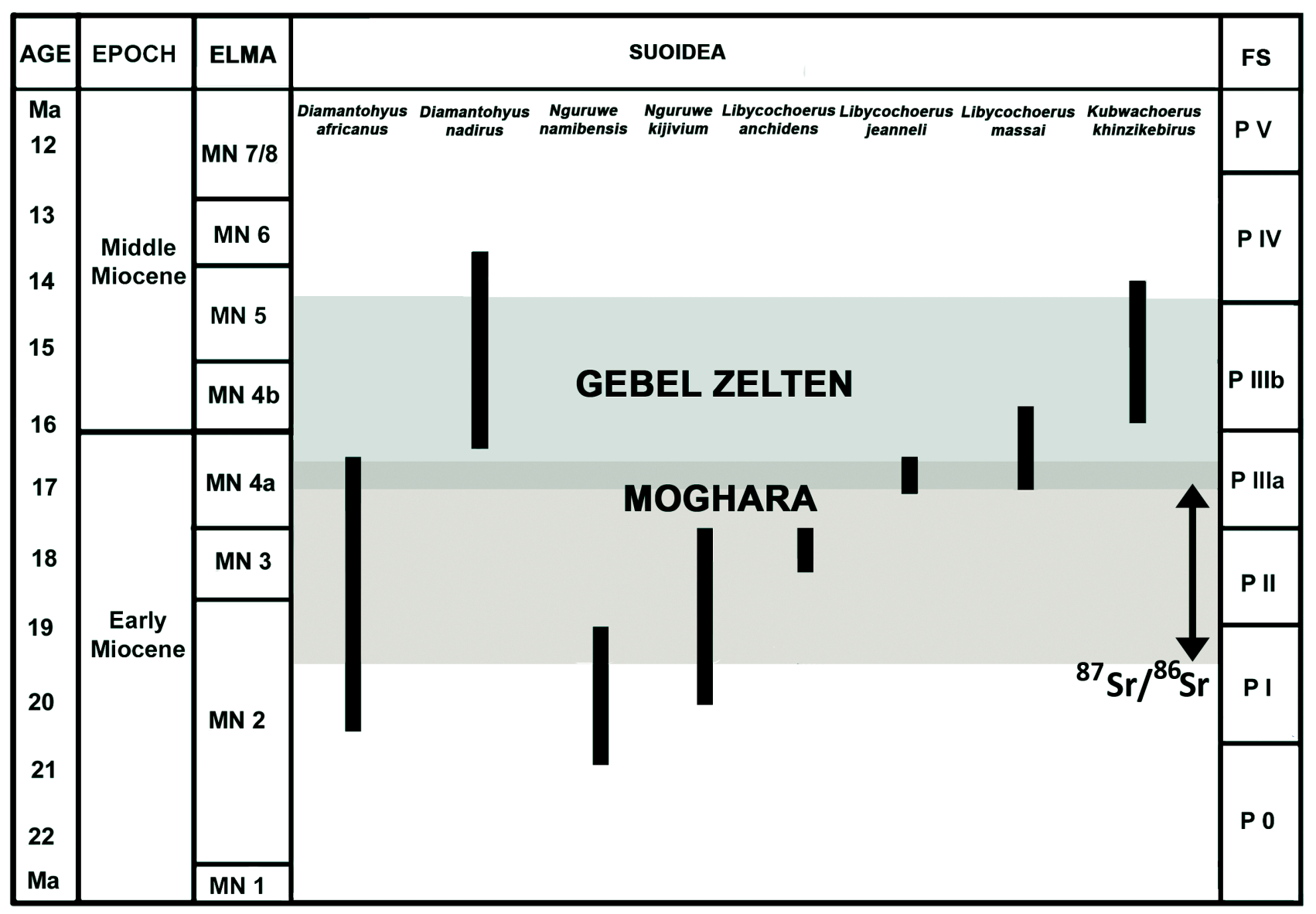

Text-fig. 17. Biostratigraphic correlations of Moghara, Egypt, and Gebel Zelten, Libya, with inferred age ranges in millions of years. ELMA - European Land Mammal Age (MN - Mammal Neogene Zone) (Mein 1989), FS - East African Faunal Set (Pickford 1981). The double-headed arrow is the range of ages obtained by Strontium isotope dating analyses (Hassan et al. 2013).

authorisation to examine the fossils from Moghara under their care. Part of the research was supported by the Wadi Moghra project which was funded by the National Science Foundation, International Collaboration Grant (NSF award \# 0403472 to Ellen Miller and Ahmed El-Barkooky), the Archie Fund of Wake Forest University to Ellen Miller and Geology Department, Faculty of Science, Cairo University (Ahmed El-Barkooky). Mohamed Abdel Gawad also received funding from the Patterson student field work grant of the Society of Vertebrate Paleontology (Berlin, Germany, November 2014). The funders had no role in study design, data collection and analysis, decision to publish, or preparation of the manuscript. The authors would like to thank Walid Kassab and Gebely Abu El-Kheir for their help in fieldwork. MHAR would like to take this opportunity to thank the team of the East Libya Neogene Research Project (ELNRP) for providing access to the vertebrate fossil storage in the University of Benghazi especially Dr. Noel Boaz, Dr. Ahmed Muftah and Dr. Moftah El-Shawaihdi. Thanks are also extended to the head of the Earth Sciences Department, University of Benghazi Dr. Awad Bilal.

\section{References}

Abdel Gawad, M. K. (2011): Geological and Paleoecological Aspects of the Moghra Fossil Mammals, North
Western Desert, Egypt; Masters Thesis. - MS, Geology Department, Faculty of Science, Cairo University, Cairo, Egypt, 245 pp. (copy in Cairo University Library)

Abdel Gawad, M. K., Miller, E. R., Hamdan, M. A., Ali, S. M., El-Sharkawy, M. A., El-Barkooky, A. N. (2010): Stratigraphic distribution of fossil mammals in the early Miocene Moghra Formation, north Western Desert, Egypt. - In: $10^{\text {th }}$ International Conference on the Geology of the Arab World (GAW10). Cairo University, Cairo, pp. 52-53.

Abdel Gawad, M. K., Miller, E. R., Hamdan, M. A., ElBarkooky, A. N., El-Sharkawy, M. A. (2012): Vertebrate and geological signatures on the construction of Moghra Formation, North Western Desert, Egypt. - Journal of Vertebrate Paleontology, SVP Program and Abstracts Book, 2012: 54.

Andrews, C. W. (1899): Fossil Mammalia of Egypt. - Geological Magazine, Ser. 4, 6: 481-484. https://doi.org/10.1017/S0016756800142682

Andrews, C. W. (1900): Fossil Mammalia from Egypt. Geological Magazine, Ser. 4, 7: 401-403. https://doi.org/10.1017/S0016756800174527

Arambourg, C. (1961): Note préliminaire sur quelques vertébrés nouveaux du Burdigalien de Libye. - Compte rendu sommaire des séances de la Société géologique de France, Sér. 7, 1961: 107-109.

https://doi.org/10.2113/gssgfbull.S7-II.2.172 
Arambourg, C. (1963): Le genre Bunolistriodon ARAMBourG, 1933. - Bulletin de la Société géologique de France, 7(5): 903-911.

https://doi.org/10.2113/gssgfbull.S7-V.6.903

Blanckenhorn, A. (1900): Neues zur Geologie und Paläontologie Aegyptens. - Zeitschrift der Deutschen geologischen Gesellschaft, 52(3): 403-479.

Blanckenhorn, A. (1901): Neues zur Geologie und Paläontologie Aegyptens. - Zeitschrift der Deutschen geologischen Gesellschaft, 53(1): 52-132.

Drake, R., Van Couvering, J. A., Pickford, M., Curtis, G., Harris, J. A. (1988): New chronology for the early Miocene mammalian faunas of Kisingiri, Western Kenya. - Journal of the Geological Society of London, 145: 479-491. https://doi.org/10.1144/gsjgs.145.3.0479

Fourtau, R. (1918): Contributions à l'étude des vertébrés miocènes de 1'Egypte. - Geological Survey of Egypt and Government Press, Le Caire, i-vii + 1-99 pp.

Fourtau, R. (1920): Contributions à l'étude des vertébrés miocènes de l'Egypte; Supplément I - Nouvelles observations sur la dentition de certains Anthracothéridés de Moghara. - Geological Survey of Egypt and Government Press, Le Caire, pp. 111-117.

Gabunia, L. K. (1958): O cherepe rogatoi iskopaemoi svinia iz srednego miotsena Kavkaza [About a skull of a horned pig from the middle Miocene of the Caucasus]. Doklady Akademii Nauk SSSR, 118(6): 1187-1190. (in Russian)

Georgialis, G. L., Abdel Gawad, M. K., Hassan, S. M., El-Barkooky, A. N., Hamdan, M. A. (2020): Oldest co-occurrence of Varanus and Python from Africa: first record of squamates from the early Miocene of Moghra Formation, Western Desert, Egypt. - PeerJ, 8: e9092 (26 pp.). https://doi.org/10.7717/peerj.9092

Gray, J. E. (1821): On the natural arrangement of vertebrose animals. - London Medical Repository, 15(1): 296-310.

Harris, J. M. (1973): Prodeinotherium from Gebel Zelten, Libya. - Bulletin of the British Museum (Natural History), Geology, 23: 283-348.

Leonardi, P. (1954): I suidi di Sahabi nella Sirtica (Africa Settentrionale) [Suids from Sahabi near Sirtica (North Africa)]. - Rendiconti del'Accademia Nazionale delle Scienze detta dei XL, Ser. 4, 4-5: 75-88. (in Italian)

Hassan, S. M. (2013): Sequence Stratigraphy of the lower Miocene Moghra Formation in the Qattara Depression, North Western Desert, Egypt. - Springer, Heidelberg, New York, Dordrecht, 160 pp.

https://doi.org/10.1007/978-3-319-00330-6

Hassan, S. M., Steel, R. J., El-Barkooky, A. N., Hamdan, M. A., Olariu, C., Helper, M. A. (2012): Stacked, lower Miocene tide-dominated estuary deposits in a transgressive succession, Western Desert, Egypt. - Sedimentary Geology, 282: 241-255. https://doi.org/10.1016/j.sedgeo.2012.09.013

Jennings-Bramley, W. (1897): A journey to Siwa in September and October, 1896. - The Geographical Journal, 10: 59.

https://doi.org/10.2307/1774908

Made, J. van der (1996): Listriodontinae (Suidae, Mammalia), their evolution, systematics and distribution in time and space. - Contributions to Tertiary and Quaternary Geology, 33(1-4): 1-253.

Mein, P. (1989): Updating of MN zones. - In: Fahlbusch, V. Mein, P., Lindsay, E. H. (eds), European Neogene Mammal Chronology. Plenum Press, New York, pp. 73-90. https://doi.org/10.1007/978-1-4899-2513-8_6

Morlo, M., Miller, E. R., Bastl, K., Abdel Gawad, M. K., Hamdan, M., El-Barkooky, A., Nagel, D. (2019): New Amphicyonids (Mammalia, Carnivora) from Wadi Moghra, Early Miocene, Egypt. - Geodiversitas, 41: 731-745. https://doi.org/10.5252/geodiversitas2019v41a21

Owen, R. (1848): Description of teeth and portions of jaws of two extinct anthracotheroid quadrupeds (Hyopotamus vectianus and $H$. bovinus) discovered by the Marchioness of Hastings in the Eocene deposits on the N.W. coast of the Isle of Wight. - Quarterly Journal of the Geological Society of London, 4: 104-141. https://doi.org/10.1144/GSL.JGS.1848.004.01-02.21

Pickford, M. (1981): Preliminary Miocene Mammalian biostratigraphy for Western Kenya. - Journal of Human Evolution, 10: 73-97. https://doi.org/10.1016/S0047-2484(81)80026-7

Pickford, M. (1984): A revision of the Sanitheriidae (Suiformes, Mammalia). - Geobios, 17: 133-154. https://doi.org/10.1016/S0016-6995(84)80139-4

Pickford, M. (1986): A revision of the Miocene Suidae and Tayassuidae (Artiodactyla, Mammalia) of Africa. - Tertiary Research Special Papers, 7: 1-83.

Pickford, M. (1995): Suidae (Mammalia, Artiodactyla) from the early Middle Miocene of Arrisdrift, Namibia: Namachoerus (gen. nov.) moruoroti, and Nguruwe kijivium. Comptes Rendus de l'Académie des Sciences, Paris, Sér. IIa, 320: 319-326.

Pickford, M. (2001): The biochronological importance of Kubanochoerinae (Mammalia, Suidae) together with a description of new material of Megalochoerus khinzikebirus and Libycochoerus massai from Kenya. - Comptes Rendus de l'Académie des Sciences, Paris, Sér. IIa, 332: 193-200. https://doi.org/10.1016/S1251-8050(01)01513-0

Pickford, M. (2006): New suoid specimens from Gebel Zelten, Libya. - Estudios Geológicos, 62(1): 499-514. https://doi.org/10.3989/egeol.0662144

Pickford, M., Kaya, T., Tarhan, E., Eryilmaz, D., Mayda, S. (2020): Small early Miocene listriodont suid (Artiodactyla : Mammalia) from Sabuncubeli (Manisa, S.W. Anatolia) Turkey. - Fossil Imprint, 76(2): 325-337. https://doi.org/10.37520/fi.2020.026

Pickford, M., Miller, E., El-Barkooky, A. N. (2010): Suidae and Sanitheriidae from Wadi Moghra, Early Miocene, Egypt. - Acta Palaeontologica Polonica, 55(1): 1-11. https://doi.org/10.4202/app.2009.0015

Pickford, M., Tsujikawa, H. (2019): Revision of African Kubanochoerinae (Suidae: Mammalia) with descriptions of new fossils from the middle Miocene Aka Aiteputh Formation, Nachola, Kenya. - Münchner Geowissenschaftliche Abhandlungen, Reihe A, Geologie und Paläontologie, 48: 1-106.

Simpson, G. G. (1945): The Principals of Classification and a Classification of Mammals. - Bulletin of the American Museum of Natural History, 85: 1-350. 
Stromer, E. (1922): Erste Mitteilung über tertiäre WirbeltierReste aus Deutsch-Südwestafrika. - Sitzungsberichte der mathematisch-physikalischen Klasse der Bayerischen Akademie der Wissenschaften zu München, 1921: 331-340.

Stromer, E. (1926): Reste Land- und Süsswasser-Bewohnender Wirbeltiere aus dem Diamantefeldern DeutschSüdwestafrikas. - In: Kaiser, E. (ed.), Die Diamantenwüste Südwest-Afrikas, Bd. 2. Dietrich Reimer, Berlin, pp. 107-153.
Wessels, W., Fejfar, O., Pelàez-Campomanes, P., Van der Meulen, A., de Bruijn, H. (2003): Miocene small mammals from Jebel Zelten, Libya. - Coloquios de Paleontologia, Supplementary Volume 1: 699-715.

Wilkinson, A. (1976): The lower Miocene Suidae of Africa. - In: Savage, R. J. G., Coryndon, S. C. (eds), Fossil Vertebrates of Africa, vol. 4. Academic Press, London, New York, San Francisco, pp. 173-282, 10 pls. 